\title{
Review on Pharmacological potentials of Prosopis juliflora
}

\author{
Miss. Manisha D. Ukande*1 Miss. Shakila Shaikh1, Dr. Krishna Murthy', Dr. Rajkumar Shete1 \\ ${ }^{1}$ Rajgad Dnyapeeth's College of Pharmacy, Bhor Pune, (M.S) India, Pin-412206
}

\begin{abstract}
Prosopis juliflora is one of the most widely used herbal plants in treating diabetes mellitus. This plant mainly belongs to the Leguminosae (Mimosaceae) family. The World Health Organization (WHO) estimates that about $80 \%$ of the population is still depends upon herbal medicines for their treatment of diseases due to various advantages such as ease of availability, economic and less side effects when compared to allopathic system of medicines. This plant has broad ecological amplitude and is adapted to a wide range of soils. It is generally found in the areas where water and soil fertility are the primary agents limiting plant growth, and is able to survive, and even thrive, on some of the poorest land, unsuitable for any other tree species. The phytoconstituents present in this plant are tannins, phenolics, flavonoids, alkaloids, terpenes and steroids. This plant shows various pharmacological activities such as anti-bacterial, antifungal, anticancer, antioxidant, and antimicrobial activity. The review of this plant suggests that the presence of flavonoids, phenolic compounds, alkaloids and other secondary metabolites are responsible for its pharmacological activities there for, the plant plays a vital role in maintenance of the human health and wellbeing. The present review deals with various pharmacological effects established on plant P. juliflora.
\end{abstract}

Keywords: Prosopis juliflora, Alkaloids,

Article Info: Received 13 June 2019; Review Completed 31 July 2019; Accepted 10 August 2019; Available online 22 August 2019

\section{Cite this article as:}

Ukande MD, Shaikh S, Murthy K, Shete R, Review on Pharmacological potentials of Prosopis juliflora, Journal of Drug Delivery and Therapeutics. 2019; 9(4-s):755-760 http://dx.doi.org/10.22270/jddt.v9i4-s.3372

\section{*Address for Correspondence:}

Miss. Manisha D. Ukande, Rajgad Dnyapeeth's College of Pharmacy, Bhor Pune, (M.S) India, Pin-412206

\section{Introduction}

The medicinal plants are widely used as a source of the medicine. The widespread use of herbal remedies and healthcare preparations is described in the Vedas and the Bible. The plants having the medicinal value have been used for several years in the conservation of food and also used to treat health disorders and also to prevent health related diseases. ${ }^{1}$ Prosopis juliflora is one of the most economically and ecologically important tree species in arid and semi-arid zones of the world.2

Prosopis juliflora belongs to the family Leguminosae (Fabaceae), sub-family Mimosoideae, and it having 44 species of which 40 are native to the Americas, three to Asia and one to Africa. The tropical Andean region is home to six species and eight species are found in the texas area, seven of them being endemic. ${ }^{3}$ These species are having the several properties such as soil binders, sand stabilizers, as well as its ability to grow in the poorest soils. 4

\section{Botanical Description}

It is a shrub or tree having 8-12 metres long. Growing to a height of up to 12 metres $(39 \mathrm{ft}), P$. juliflora has a trunk diameter of up to 1.2 metres $(3.9 \mathrm{ft}) .^{5}$ Its leaves are deciduous, geminate-pinnate, light green, with 12 to 20 leaflets. Flowers appear shortly after leaf development. The flowers are in 5-10 cm long green-yellow cylindrical spikes, which occur in clusters of 2 to 5 at the ends of branches. Pods are 20 to $30 \mathrm{~cm}$ long and contain between 10 and 30 seeds per pod. A mature plant can produce hundreds of thousands of seeds. Seeds remain viable for up to 10 years. The tree reproduces solely by way of seeds, not vegetative. Seeds are spread by cattle and other animals, which consume the seed pods and spread the seeds in their droppings. 6 The tree is said to have been introduced to Sri Lanka in the 19th century, where it is now known as vanniandara, or katu andara in Sinhala. It is claimed that $P$. juliflora existed and was recognized even as a holy tree in ancient India, but this is most likely confusion with Prosopis cineraria. The tree is believed to have existed in the Vanni and Mannar regions for a long time.7,8 In the western extent of its range in Ecuador and Peru, Prosopis juliflora readily hybridizes with Prosopis pallida and can be difficult to distinguish from this similar species or their interspecific hybrid strains. ${ }^{9}$ Tap roots contribute to a stable anchoring of the tree and expand towards ground water reserves. They are essential during periods of drought when only deep water sources are available. The depth of the roots depends on the quality and structure of the soil and the availability of soil water; it is also determined by the density of the stand. 

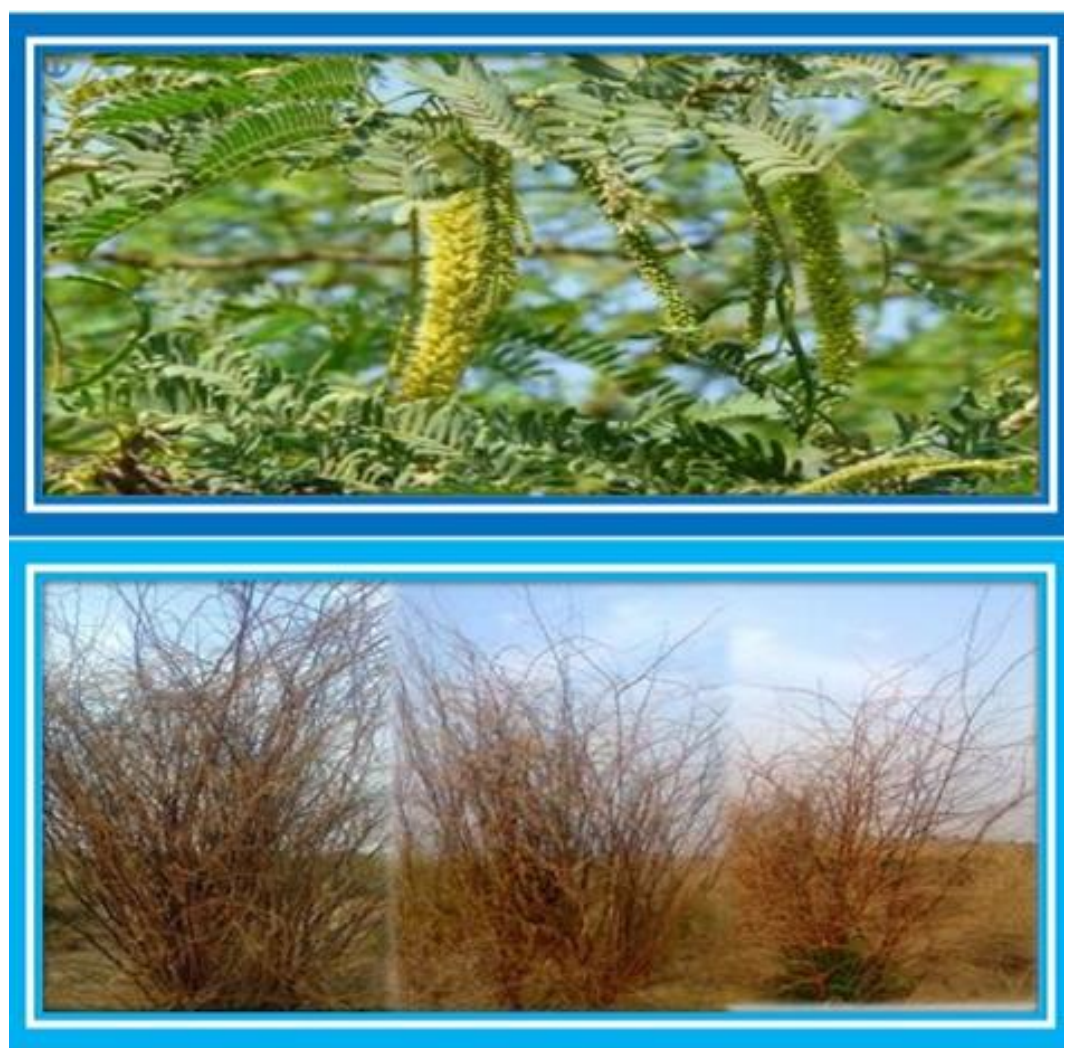

Fig 1: Mesquite: Prosopis juliflora

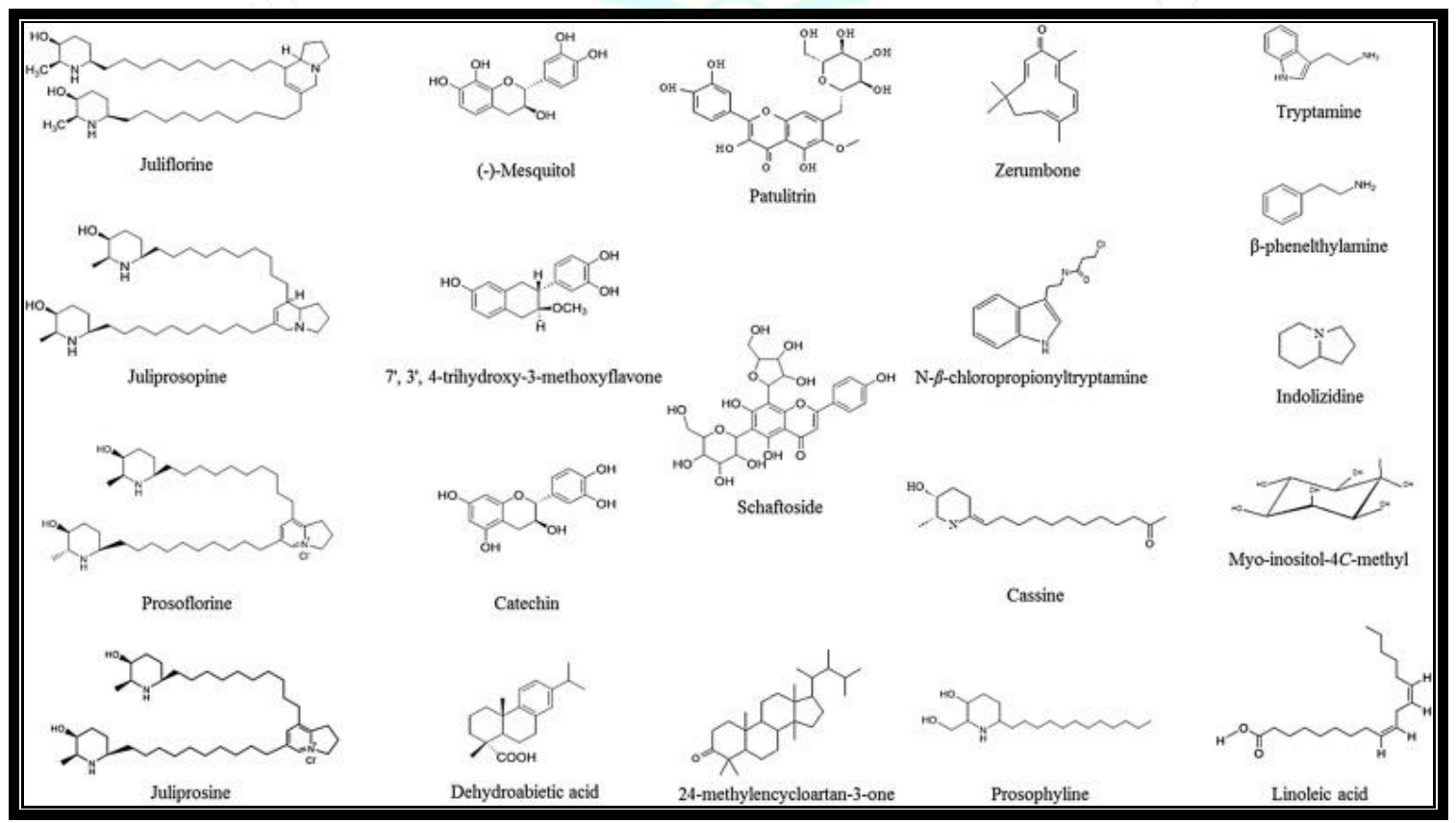

Fig 2: Chemical structures of Prosopis spp. having medicinal properties.

\section{Beneficial impacts of $P$. juliflora}

The various chemical agents that are present in it show the medicinal value that may alters certain physiological actions in the human body. The several biochemicals present in the plant are terpenes, alkaloids, flavonoids and phenolic compounds. Terpenes are used as insecticides and their pharmacological properties include antibacterial, antifungal, anthelmintic, antimalarial and molluscicidal.10 Extracts of $P$. juliflora seeds and leaves have several in vitro pharmacological effects such as anti-bacterial, anti-fungal and anti-inflammatory properties. ${ }^{11}$
Scince it is a main source of fuel for both urban and rural poor in the country, this plant provides more than $90 \%$ of the fuel wood in some Indian villages because $P$. juliflora wood has excellent burning qualities. Thus, it is called wooden anthracite. It also has high calorific value. The wood obtained from this plant doesn't need storage and drying process. ${ }^{12}$

It also contains high flavonoidal content $16 \%$ which shows the antioxidant and anticancer properties. The tannins and phenol content is very low i.e. ( 0.33 and $0.66 \%$ respectively) which can synergize the antioxidant and anticancer potential 
of flavonoids. Phenols showed the property to prevent the platelets from clumping and also have anti-inflammatory properties. It also acts as immune enhancer, anticlotting and hormone modulators. Tannins in the plant cell inhibit hydrolytic enzymes like proteolytic macerating enzymes used by plant pathogens. ${ }^{13,14}$
This plant also helps in preventing the fungal and mycotoxin contamination. Therefore there is an absolute need for bioactivity guided fractionation and isolation of the active components from the plant extracts found to be effective.15

Table1. Promising bioactive botanicals from $P$. juliflora

\begin{tabular}{|c|c|c|}
\hline Name of compounds & Class of compound (source) & Pharmacological activity \\
\hline Mesquitol & Flavonoid (Bark) & Antioxidant \\
\hline Juliflorine & Alkaloid (Leaves) & Antialzheimer agent \\
\hline Seco-juliprosopinal & Alkaloid (Leaves) & Plant growth inhibition \\
\hline Juliprosine & Alkaloid (Leaves) & Antifungal agent \\
\hline Isojuliprosine & Alkaloid (Leaves) & Antifungal agent \\
\hline Juliprosinene & Alkaloid (Leaves) & Antibacterial agent \\
\hline
\end{tabular}

\section{Pharmacological activities of Prosopis juliflora}

\section{Antibacterial Activity}

The several alkaloid constituents present in the Prosopis juliflora were assessed for their antibacterial property using disc diffusion method on several Gram-negative and Grampositive bacterial strains like E.coli, Staphylococcus aureus, etc. The maximum antibacterial effect is shown by the part of the plant such as leaf, pod and flower extract, with MIC [Minimum inhibitory concentration] value ranging between $25 \mu \mathrm{g} / \mathrm{ml}-100 \mu \mathrm{g} / \mathrm{ml}$. The extract of leaves showed the maximum activity among of all the other parts.

The bacteria such as Klebsiella was found to be the most susceptible bacteria, whereas Acinetobacter and Alcaligen were the least susceptible. These bacteria affected by the alkaloidal extract of the plant while it is not affected by the use of antibiotics. 16

\section{Antifungal Activity}

The aqueous extract of the leaves are involved in showing the fungicidal activity either by using in the combination or used alone. The aqueous extract exhibited maximum fungicidal activity at $24 \%$ concentration. Methanol and ethanol extracts recorded highly significant antifungal activity. ${ }^{\mathbf{1 7}}$ It was reported that this plant contains a variety of alkaloids having different biological activities including broad spectrum antifungal activity against a wide range of seed-borne fungi.

The combination of chemical fungicides amended with alkaloid extract showed highly significant antifungal activity compared to chemical fungicides alone tested at the recommended dosage. 18

\section{Antagonistic Effect}

The methanolic crude extract of $P$. Juliflora showed the inhibition of the bacteria. The well diffusion test was performed on two tested Gram-negative bacteria (E. coli and Klebsiella sp.) and three Gram-positive bacteria (Staphylococcus aureus, Bacillus sp. and Streptococcus sp.) indicated inhibition of all tested bacteria. The leaves extract of this plant showed the inhibition on all tested bacteria with 22 and $19 \mathrm{~mm}$ zone of inhibition against Streptococcus $s p$., and Bacillus sp., respectively, whereas dry leaves revealed intermediate inhibition. ${ }^{17}$

\section{Anti-Tumor Activity}

Several alkaloid extracts are involved in showing the cytotoxic activity. The in vitro anti-tumor potential of the extract was evaluated using MTT (3-(4,5- dimethythiazol2yl) 2,5- diphenyl tetrazolium bromide) based cytotoxicity monitoring after 24, 48 and $72 \mathrm{~h}$ exposure of the MOLT-4 cells $(1 \times 106$ cells $/ \mathrm{ml}$ medium $)$ to different concentration of the extract ranging from 10 to $100 \mu \mathrm{g} / \mathrm{ml}$ medium. The extract exhibited comparatively higher toxicity towards the cancer cells than the normal cells at all the tested concentrations and at all the time points studied.19

Prosopis juliflora (Sw.) DC contains many alkaloids such as juliflorine, julifloricine and julifloridine, juliprosine, juliprosinine and juliflorinine are found to be responsible for the biological activity. ${ }^{20}$

\section{Anti-oxidant Activity}

It has been reported that several flavonoids as well as phenolic acid contents and profiles play a significant role in determining the particular antioxidant capacity of pollen of different botanical origin. Compounds possessing reactive phenolic hydroxyl groups are endowed with an important antioxidant property in vitro particularly those possessing the 0-dihydroxyl structure in $30^{\text {th }}$ and $40^{\text {th }}$ position of the B ring in the structure of flavonoids. ${ }^{21}$ The antioxidant capacity as lipid peroxidation inhibitor in in vitro biological systems of mesquite honeybee-collected pollen is as high as that of pollen of Amaranthus hybridus and that of a complex mixture of honeybee-collected pollen formed by six monofloral pollens from Durango, Mexico, analyzed under similar conditions, ${ }^{22}$ all of them with a particular flavonoid composition.

\section{Anti-diabetic activity}

Many anti-diabetic plants have a necessary role to treat diabetes mellitus because they have a strong action to decrease hyperglycemia. The terpenes isolated from this plant are generally used in the management of diabetes. The medicinal value of plants can be observed from the chemical agents they possess, which may alter certain physiological actions in the human body. The most important of these biochemically active compounds of plants are terpenes, alkaloids, flavonoids and phenolic compounds. Terpenes are used as insecticides and their pharmacological properties include antibacterial, antifungal, antimalarial and mollusccidal. 23

\section{Anthelmintic Activity:}

The plant part of P.juliflora mainly roots and leaves have shown the Anthelmintic activity against adult Haemonchus contortus, with activity comparable to Albendazole, a synthetic anthelmintic drug. The anthelmintic activity 
performed by Egg Hatch Assay and In vitro Ovicidal Activity. Ethanolic extracts of root (REE) and leaf (LEE) of $P$. juliflora were found to exhibit in vitro activity against adult Haemonchus contortus, with activity comparable to Albendazole, a synthetic anthelmintic drug. The anthelmintic activity of LEE was significantly higher than REE $(\mathrm{P} \leq 0.05)$ but lower than ALB. The observed in vitro anthelmintic activity was attributed to saponins and condensed tannins and perhaps to alkaloids present in the plant. Phytochemical analysis confirmed presence of tannins, saponins and alkaloids, among other phytoconstituents. ${ }^{24}$

\section{Antipyretic Activity:}

The ethanolic extract of the plant Prosopis juliflora has shown its potential, effective and safer anti-pyretic activity. To examine antipyretic activity male rats divided into four groups. Group 1 was treated with water for injection $(100$ $\mathrm{ml} / \mathrm{kg}$ ). Group 2 treated with Paracetamol $(150 \mathrm{mg} / \mathrm{kg}$ p.o dissolved in water for injection). Group 3 and 4 were treated with ethanol extract of Prosopis juliflora (250 and 300 $\mathrm{mg} / \mathrm{kg}$ p.o respectively). In this activity paracetamol was used as the standard drug in which the rectal temperature was reduced at 3 hours and at dose $500 \mathrm{mg} / \mathrm{kg}$. Significantly reduced the rectal temperature at 2,3 and 4 hours in comparison with vehicle control. ${ }^{25}$

\section{Antiulcer Activity:}

The ethanolic extract of the plant Prosopis juliflora examined for the antiulcer activity in wistar rats. The rats divided into four groups. Group 1 was treated with water for Injection (10 ml/kg). Group 2 was treated with Ranitidine $(50 \mathrm{mg} / \mathrm{kg}$ p.o dissolved in water for Injection). Groups 3 and 4 were treated with ethanol extract of Prosopis juliflora (250 and $500 \mathrm{mg} / \mathrm{kg}$ p.o. respectively). The ethanolic extract of the plant Prosopis juliflora (250 and $500 \mathrm{mg} / \mathrm{kg}$ ) significantly shows the reduction of the ulcer score in comparison with ethanol induced ulcer control.26

\section{Antigiardial and Amoebicidal Activity:}

Giardiasis is the most common cause of parasitic gastrointestinal disease. Giardia is a flagellate protozoan with worldwide distribution that causes significant gastrointestinal diseases in a wide variety of vertebrates including cats and human. The highest activity against Giardia lamblia, with respect to time, was obtained from petroleum ether extract which exhibited 78.91\% mortality within $72 \mathrm{~h}$ with a concentration of $500 \mathrm{ppm}$ followed by the methanolic extract which exhibited $77.48 \%$ mortality within $72 \mathrm{~h}$ with a concentration of $1000 \mathrm{ppm}$. The highest activity against Entamoba histolytica, with respect to time, was obtained from methanolic extract which exhibited $71.97 \%$ mortality within $72 \mathrm{~h}$ with a concentration of 1000 ppm. ${ }^{27}$

\section{Antipustule Activity}

The Acetone extract of plant Prosopis juliflora (AEP) shows the effective anti-pustule activity by inhibiting Staphylococcus species through well diffusion method. Minimum inhibitory concentration of AEP showed the activity. This inhibitory action was also confirmed by growth curve analysis. ${ }^{28}$

Table 2. Medicinal effects of bioactive substances from parts of the Prosopis spp (Leguminosae, Mimosaceae).

\begin{tabular}{|c|c|c|c|c|}
\hline Prosopis species & $\begin{array}{l}\text { Prosopis } \\
\text { species }\end{array}$ & Medicinal effects & Bioactive components & Ref \\
\hline \multirow[t]{6}{*}{ P. juliflora } & Leaves & $\begin{array}{l}\text { Inhibition of acetyl } \\
\text { cholinesterase Blocking calcium } \\
\text { channels }\end{array}$ & Juliflorine & 29 \\
\hline & Leaves, pods & $\begin{array}{l}\text { Decreasing gas production } \\
\text { during ruminal digestion }\end{array}$ & Prosoflorine & 30 \\
\hline & Fruits & Activity against lung carcinoma & Patulitrin & 31 \\
\hline & Heart wood & Antioxidant activity & ()-Mesquitol & 32 \\
\hline & Leaves & $\begin{array}{l}\text { Inhibition of drug-resistant } \\
\text { fungi } \\
\text { Glial cell activation } \\
\end{array}$ & Piperidine alkaloids & 33 \\
\hline & Seeds, leaves & $\begin{array}{l}\text { Inhibition of } \mathrm{H}+, \mathrm{K}^{+} \text {, ATPase of } \\
\text { H. pylori }\end{array}$ & $\begin{array}{l}\text { Alkaloids, flavonoids, tannins, } \\
\text { anthraquinones, and quinones }\end{array}$ & 34 \\
\hline P. cineraria & Pods & Antioxidant activity & Triterpenoids Prosophyline & 35 \\
\hline \multirow[t]{2}{*}{ Prosopis africana } & $\begin{array}{l}\text { Leaves, roots and } \\
\text { Stem }\end{array}$ & Antitripanosomal activity & Tannins & 36 \\
\hline & Stem bark & Anti-inflammatory activity & Flavonoids & 37 \\
\hline P. chilensis & Leaves & DNA binding activity & $\begin{array}{l}\text { b-phenethylamine } \\
\text { Tryptamine }\end{array}$ & 38 \\
\hline \multirow[t]{2}{*}{$\begin{array}{l}\text { Prosopis glandulosa } \\
\text { var. glandulosa }\end{array}$} & Leaves & Anti-infective & Indolizidine & 39 \\
\hline & & Antiparasitic & Indolizidine & 40 \\
\hline Prosopis flexuosa & Aerial parts & Antioxidant activity & Catechin & 41 \\
\hline Prosopis tamarugo & Leaves & Antioxidant activity & Catechin & 42 \\
\hline P. alpataco & Seed & Antibacterial activity & Pentacyclic triterpenes & 43 \\
\hline Prosopis pallida & Fruit & Antihyperglycemia & Phenolic compound & 44 \\
\hline P. cineraria & Whole plant & Anticonvulsant activity & Alkaloids & 45 \\
\hline
\end{tabular}




\section{Medicinal applications of Prosopis juliflora ${ }^{46}$}

$>$ The syrup obtained by the ground up pods having the medicinal values.

$>$ It is given to the children in weight deficiency or retardation in motor development.

$>$ It is also involved in increasing lactation.

$>$ It is used for preparing various medicinal syrups, particularly for expectorants.

$>$ The leaves of the plant are used in the treatment of oral infections, painful and frequent urination.

$>$ The powdered leaves are brewed in water and the liquid applied to the eyes to treat irritations, conjunctivitis etc.

$>$ A compress made from the boiled leaves is applied to the eyes to reduce swelling.

$>$ Tea made from Prosopis juliflora is thought to be good for treating digestive disturbances.

$>$ The leaves have been shown to have antibacterial, antibiotic, antispasmodic and astringent properties.

\section{Conclusion}

Prosopis juliflora possess versatile medicinal properties. Prosopis juliflora has been proved to be effective as anthelmintic, antioxidant, antipyretic, antiulcer, cytotoxicity effect, antigiardial, amoebicidal, antipustule activity and many more. Hence in this review article effort has been taken to collect and compile the details regarding Prosopis juliflora, which will be useful to the society to venture into the further unrevealed pharmacological actions of Prosopis juliflora and also venture into the field of alternative system of medicine. The plant is a rich source of natural constituents, especially for flavonoids, alkaloids and saponins. Prosopis juliflora which is also known as mesquite locally has various pharmacological actions which can contribute a lot to the world's health as herbal plant. Various parts of herbal plant Prosopis juliflora are used like leaves, bark, twigs, flowers, fruits and pods in treatment for various therapeutic effects.

\section{References:}

1. Singh R. Medicinal Plants: A Review. Journal of Plant Sciences. Special Issue: Medicinal Plants. Vol. 3, No. 1-1, 2015, pp. 50-55.

2. Pasiecznik NM, Felker P, Harris PJ, Harsh L, Cruz G, Tewari JC, Cadoret K, Maldonado LJ. The 'Prosopis Juliflora'-'Prosopis Pallida' Complex: A Monograph. Coventry: HDRA; 2001.

3. Kwalter, Prosopis, an Alien among the Sacred Trees of South India Academic Dissertation, University of Helsinki, Viikki Tropical Resources Institute, 2011.

4. C.Y. Michel-López, D. González-Mendoza and O. Grimaldo Juarez, Fast protocol for extraction of DNA from Prosopis sp. leaves (plant adapted to arid environment) without liquid nitrogen, Genetics and molecular research journal, 12 (3): 4090-4094, (2013).

5. "Prosopis juliflora". www.hort.purdue.edu. Retrieved 2008-05-01.

6. Lalith Gunasekera, Invasive Plants: A guide to the identification of the most invasive plants of Sri Lanka, Colombo 2009, pp. 101102.

7. Phillips, W. S. (1963). "Depth of Roots in Soil". Ecology. 44 (2): 424967.

8. Raven, Peter H.; Evert, Ray F.; Eichhorn, Susan E., eds. (2005). "Chapter 24". Biology of Plants (7th ed.). New York, USA: Freeman. pp. 528-546.
9. Pasiecznik, Harris, and Smith (2004). Identifying Tropical Prosopis Species (PDF). Coventry, UK: Henry Doubleday Research Association.

10. Gurib-Fakim A. (2006) Medicinal plants: Tradition of yesterday and drugs of tomorrow. Mol Aspects Med 27:1-93.

11. Kanthasamy A, Subramanian S, Govindasamy S. (1989) Bactericidal and fungicidal effects of Prosopis juliflora Alkaloidal fraction. Ind Drugs 26:390-394.

12. k Saraswathi, NArun Nagendran. Karthigaichamy $\mathrm{R}$ and Chandrasekaran S; Livelihood support from an invasive species Prosopis juliflora.,INT J CURR SCI, 31-36,2012.

13. Mibrahim, K nadir, Aali, V ahmad, Mrasheed, Phytochemical analyses of Prosopis juliflora swartz dc. Pak. J. Bot., 45(6): 21012104, 2013.

14 N. Deepa, S. Chandra Nayaka, K. Girish, M.P. Raghavendra Synergistic effect of Prosopis juliflora extract and chemical fungicides against seed borne toxigenic fungi, International journal of advanced life sciences Vol 6(4), 2013, 312-317.

15. Theddeus M. Kiswii, Ethel O. Monda, Paul O. Okemo, Christine Bii, Amos E. Alakonya, Efficacy of Selected Medicinal Plants from Eastern Kenya against Aspergillus flavus, Journal of Plant Sciences. Vol. 2, No. 5, 2014, pp. 226- 231.

16. Edilene T. dos Santos , Mara Lúcia A. Pereira , Camilla Flávia P.G. da Silva et al Antibacterial Activity of the Alkaloid Enriched Extract from Prosopis juliflora Pods and Its Influence on in Vitro Ruminal Digestion, International Journal of Molecular Sciences 2013, 14(4), 8496-8516.

17. M.P. RaghavendraS. Satish and K.A. Raveesha Alkaloid extracts of Prosopis juliflora (Sw.) DC. (Mimosaceae) against Alternariaalternata Journal of Biopesticides, 2(1): 56-59 (2009).

18. Dale W. Young; Factors Affecting the Translocation of Herbicides in Mesquite (Prosopis Juliflora) - 1950 All Graduate Theses and Dissertations. Paper 1694

19. M Sathiya, K Muthuchelian; Anti-tumor potential of total alkaloid extract of Prosopis juliflora DC. leaves against Molt-4 cells in vitro; African Journal of Biotechnology Vol 10(44), 2011

20. N M., and J K. Githiomi Fuel-wood energy properties of Prosopis juliflora and Prosopis pallida grown in Baringo District, Kenya, African Journal of Agricultural Research Vol. 8(21), 2476-2481, 6 June, 2013

21. Zhang, J., Shen, S., 1997. Antioxidant activities of baicalin, green tea polyphenols and alizarin in vitro and in vivo. Journal of Nutrition and Environmental Medicine 7, 79-89

22. Rice-Evans, C., 1999. Screening of phenolics and flavonoids for antioxidant activity. In: Packer, L., Midori, H., Toshikazu, Y. (Eds.), Antioxidant Food Supplements in Human Health. Academic Press, USA, pp. 239-253.

23. Donga JJ, Surani VS, Sailor GU, Chauhan SP, Seth AK. (2011) A systematic review on natural medicine used for therapy of diabetes mellitus of some Indian medicinal plants. Int J Pharm Sci $2: 36$.

24. S. O. Rechab et al., Phytochemical and In vitro anthelmintic studies of Prosopis juliflora (sw.) dc (fabaceae) extracts against Haemonchus contortus, an ovine nematode.

25. Gopinath S.M et al., To evaluate the antipyretic activity of Prosopis juliflora ethanolic extract in brewer's yeast induced hyperthermia in rats. Journal of Biotechnology and Biosafety. Vol-1, Issue 2, September-October 2013, 28-32.

26. Jagan Mohan Reddy $\mathrm{P}$ et al., Evaluation of antiulcer activity of Prosopis juliflora ethanol extract in ethanol induced gastric ulceration in rats. International Journal of Pharmacy review and research. Vol 4; Issue 1; 2014; Page no: 17-20.

27. Mohammed I. Garbi et al., Antigiardial, Amoebicidal and Cytotoxic activity of the plant Prosopis juliflora leave extracts. Merit Research Journal of Biochemistry and Bioinformatics Vol. 2(2) pp. December, 2014. 
28. Rajadurai Jesudoss R P et al., Screening of anti-pustule plant metabolites from Prosopis juliflora and their combined antipustule activity with synthetic pimple creams. Journal of Chemical and Pharmaceutical Sciences Issue 2: October 2014 Page no: 145-150.

29. Choudhary MI, Nawaz SA, Azim MK, Ghayur MN, Lodhi MA, Jalil S, Khalid A, Ahmed A, Rode BM, Ahmad VU. Juliflorine: a potent natural peripheral anionic-site-binding inhibitor of acetylcholinesterase with calcium-channel blocking potential, a leading candidate for Alzheimer's disease therapy. Biochemical and biophysical research communications. 2005 Jul 15;332(4):1171-9.

30. dos Santos E, Pereira M, da Silva C, Souza-Neta L, Geris R, Martins D, Santana A, Barbosa L, Silva H, Freitas G, Figueiredo M. Antibacterial activity of the alkaloid-enriched extract from Prosopis juliflora pods and its influence on in vitro ruminal digestion. International journal of molecular sciences. $2013 \mathrm{Apr}$ 17;14(4):8496-516.

31. Sathiya M, Muthuchelian K. Evaluation of antioxidant and antitumor potentials of Prosopis juliflora DC. leaves in vitro. Pharmacology online. 2010;2:328-43.

32. Sirmah P, Mburu F, Iaych K, Dumarçay S, Gerardin P. Potential antioxidant compounds from different parts of Prosopis juliflora. Journal of tropical forest science. 2011 Apr 1:187-95.

33. Valli S, Gokulshankar S, Mohanty BK, Ranjit MS, Ashutosh SR, Remya V. Antistreptococcal activity of alkaloid rich fraction of leaves of Prosopis juliflora future promising supplementary therapy for cryptococcosis and cryptococcal meningitis. Int J Pharm Pharmacol Sci 2014;6:490 .

34. Silva AD, Silva AR, Pinheiro AM, Freitas SR, Silva VD, Souza CD, Hughes JB, El-Bachá RD, Costa MF, Velozo ES, Tardy M. Alkaloids from Prosopis juliflora leaves induce glial activation, cytotoxicity and stimulate NO production. Toxicon. 2007 Apr 1;49(5):60114 .

35. YEAST EE. To evaluate the antipyretic activity of Prosopis juliflora ethanolic extract in brewer's yeast induced hyperthermia in rats. Journal of Biotechnology. 2013 Sep;1(2):28-32.

36. Liu Y, Singh D, Nair MG. Pods of Khejri (Prosopis cineraria) consumed as a vegetable showed functional food properties. Journal of Functional Foods. 2012 Jan 1;4(1):116-21.
37. Atawodi SE, Ogunbusola F. Evaluation of anti-trypanosomal properties of four extracts of leaves, stem and root barks of Prosopis africana in laboratory animals. Biokemistri. 2009;21(2).

38. Elmezughi J, Shittu H, Clements C, Edrada-Ebel RA, Seidel V, Gray A. Bioactive natural compounds from Prosopis africana and Abies nobili. Journal of Applied Pharmaceutical Science. 2013;3(3):40-3.

39. Astudillo L, Schmeda-Hirschmann G, Herrera JP, Cortés M. Proximate composition and biological activity of Chilean Prosopis species. Journal of the Science of Food and Agriculture. 2000 Apr;80(5):567-73.

40. Rahman AA, Samoylenko V, Jacob MR, Sahu R, Jain SK, Khan SI, Tekwani BL, Muhammad I. Antiparasitic and antimicrobial indolizidines from the leaves of Prosopis glandulosa var. glandulosa. Planta medica. 2011 Sep;77(14):1639-43.

41. Tapia A, Feresin GE, Bustos D, Astudillo L, Theoduloz C, Schmeda-Hirschmann G. Biologically active alkaloids and a free radical scavenger from Prosopis species. Journal of ethnopharmacology. 2000 Jul 1;71(1-2):241-6.

42. Cattaneo F, Costamagna MS, Zampini IC, Sayago J, Alberto MR, Chamorro V, Pazos A, Thomas-Valdés S, Schmeda-Hirschmann G, Isla MI. Flour from Prosopis alba cotyledons: A natural source of nutrient and bioactive phytochemicals. Food chemistry. 2016 Oct 1;208:89-96.

43. Mazzuca M, Kraus W, Balzaretti V. Evaluation of the biological activities of crude extracts from Patagonian Prosopis seeds and some of their active principles. Journal of herbal pharmacotherapy. 2003 Jan 1;3(2):31-7.

44. Pinto MD, Ranilla LG, Apostolidis E, Lajolo FM, Genovese MI, Shetty K. Evaluation of antihyperglycemia and antihypertension potential of native Peruvian fruits using in vitro models. Journal of medicinal food. 2009 Apr 1;12(2):278-91.

45. Sachdeva S, Kaushik V, Saini V. A review on phytochemical and pharmacological potential of Prosopis cineraria. Int J Ethnobiol Ethnomed. 2014;1:1e4.

46. Henciya S, Seturaman P, James AR, Tsai YH, Nikam R, Wu YC, Dahms HU, Chang FR. Biopharmaceutical potentials of Prosopis spp.(Mimosaceae, Leguminosa). journal of food and drug analysis. 2017 Jan 1;25(1):187-96. 